\title{
REAL EXCHANGE RATE BEHAVIOUR AND ECONOMIC GROWTH: EVIDENCE From SIERRA LEONE
}

\author{
Abu Bakarr Tarawalie \\ Department of Economics, University of Sierra Leone \\ Accepted January 2010
}

\begin{abstract}
The main focus of this paper is to examine the impact of the real effective exchange rate on economic growth in Sierra Leone. First an analytical framework is developed to identify the determinants of the real effective exchange rate. Using quarterly data and employing recent econometric techniques, the relationship between the real effective exchange rate and economic growth is then investigated. A bivariate Granger causality test was also employed as part of the methodology to examine the causal relationship between the real exchange rate and economic growth. The empirical results suggest that the real effective exchange rate correlates positively with economic growth, with a statistically significant coefficient. The results also indicate that monetary policy is relatively more effective than fiscal policy in the long run, and evidence of the real effective exchange rate causing economic growth was profound. In addition, the results showed that terms of trade, exchange rate devaluation, investment to GDP ratio and an excessive supply of domestic credit were the main determinants of the real exchange rate in Sierra Leone.
\end{abstract}

Keywords: Economic growth, real effective exchange rate, Johanssen Cointegration, Sierra Leone

JEL E63, F31, 41, 43

\section{1 Introduction}

The relationship between the real effective exchange rate and economic growth is certainly an important issue, from both the descriptive and policy prescription perspectives. Since the late 1980s, the Sierra Leonean economy has undergone significant changes. The switch to export-led growth from import substitution resulted in the lifting of major restrictions on the economy placed on it by the government, including the liberalisation of the current account and the implementation of a floating exchange rate regime. The major economic problems during the period were inflation and declining output. Output growth performance was poor after the 1970s and 1980s, and remained negative in the 1990s. In recent years, policy discussions have increasingly included references to real exchange rate stability and correct exchange rate alignment as crucial elements in the improvement of economic performance in Sierra Leone. Real effective exchange rate movement affects economic activity in Sierra Leone, mainly owing to its dependence on imported capital goods and specialisation in commodity exports. The country has experienced a series of exchange rate depreciations in an effort to improve output growth. The government has considered the exchange rate to be an important macroeconomic instrument for ensuring a low inflation rate and a stable financial system, promoting exports, controlling imports, and enhancing economic growth.

In the literature, the real exchange rate ${ }^{1}$ serves as a better international price for determining the competitiveness of a given country than the nominal exchange rate. Management of the nominal exchange rate depends on the real 
exchange rate, which is influenced by, inter alia, the nominal exchange rate (Montiel, 1997). Studies have shown that misalignment of the real exchange rate occurs in markets in which actual exchange rates are not allowed to adjust to changes in economic fundamentals (Prick \& Vollrath, 1994). An overvalued real exchange rate affects the pattern and level of production, the allocation and level of expenditure, the distribution and level of factor payments, the composition and size of trade flows, the level of international reserves and external debts, the parallel foreign exchange markets, currency substitution and capital flight. Further, persistent real overvaluation also seriously erodes business and consumer confidence, thereby lowering the rate of savings and investment, with an adverse impact on economic growth.

The empirical literature is replete with studies that link the real effective exchange rate with GDP. The literature identifies two channels by means of which real exchange rate affects GDP; these are the aggregate demand and aggregate supply channels. In the aggregate demand channel, a depreciation of the real effective exchange rate enhances the international competitiveness of domestic goods, boosts net exports and hence increases GDP. The aggregate supply channel posits that the depreciation of the real exchange rate increases the cost of production (and hence reduced GDP) and helps redistribute income in favour of the rich. While some of these studies argue that real depreciation has expansionary effects on real output growth (Cooper, 1971; Gylfson \& Schmid, 1983), others have argued that real exchange rate depreciation has contractionary effects (Edwards, 1989; Agénor, 1991; Morley, 1992). In view of these conflicting results, it is clear that the impact of exchange rate devaluation on real output growth remains an unresolved issue in the empirical literature.

This study therefore examines the relationship between the real effective exchange rate and output growth (GDP) in Sierra Leone. Specifically, it determines the impact of the real effective exchange rate on real output growth (RGDP). This paper is not only an attempt to contribute to the empirical debate vis-à-vis the exchange rate devaluation and the real output growth nexus, but also differs from previous studies in several respects. First, this paper examines the econometric relationship between the real effective exchange rate and RGDP growth in Sierra Leone, a small open economy in sub-Saharan Africa (SSA) which experienced a declining output growth in the 1970s, 80s and 90s. Second, Sierra Leone provides a unique context for an empirical investigation of the relationship between the exchange rate and real output growth because of its experience with foreign exchange rate devaluations since 1964. Third, the paper identifies the determinants of the real effective exchange rate in Sierra Leone. In addition, the study employed a bivariate Granger Causality test to determine the direction of causality between real exchange rate and real GDP. Finally, an investigation of the effectiveness of monetary and fiscal policies on real output growth under exchange rate regimes with considerable depreciation was also pursued. The test of the effectiveness of monetary and fiscal policies is important in ascertaining the validity and universal applicability of economic theory, which suggests that the monetary policy or fiscal policy effectiveness depends on the exchange rate policy.

The remainder of the paper is organised as follows. Section II provides a brief overview of Sierra Leone's economic performance, focusing on its exchange rate policy and real output growth since the 1970s. Section III discusses the determinants of the real effective exchange rate. In section IV, the relationship between the real effective exchange rate and real GDP growth is explored. The section presents the literature, methodology and discusses the empirical results. Section $\mathrm{V}$ is devoted to the conclusions and lessons for policy arising from the study.

\section{2 \\ Brief overview of Sierra Leone's economic performance}

After Sierra Leone gained independence in 1961, its annual economy grew by nearly 4 per cent during that decade. The fiscal and foreign exchange position was healthy, as evidenced by low inflation, despite the first oil shock in the first half of the 1970s. However, its economic 
growth slowed to about 1 per cent per year in the latter part of that decade because of falling incomes in the mining sector. In fact, Sierra Leone's economic decline started shortly after the first oil shock of the 1970s, after which the economy was characterised by severe imbalances due to inappropriate macroeconomic policies and negative external shocks. The Sierra Leonean economy lost its international competitiveness owing to unfavorable terms of trade, the deteriorating balance of trade, and an unsustainable balance of payment deficits. During this period, real GDP growth was anemic and was coupled with high inflation, high unemployment, and huge fiscal deficits, which were financed mainly by borrowing from the Central Bank. This led ultimately to increases in money supply, and consequently in high inflationary pressures.

In the first half of the 1980 s, economic conditions deteriorated sharply because of the massive drop in official diamond exports (from 16 per cent of GDP in $1980 / 81$ to 5 per cent in $1985 / 86$ ) and the reduction in the country's tax base. Economic conditions worsened during the 1990s, because the civil war resulted in capital outflow, while trade sanctions complicated the management of the exchange rate and blurred the objectives of macroeconomic policies. The Sierra Leonean economy rebounded after the civil war with a robust economic performance, especially during 2000-6, owing to the recoveries in the agricultural and mining sectors. Since then, the country has been on a sustained, strong path of economic recovery with real GDP growth increasing from 3.8 per cent in 2000 to 7.4 per cent in $2004 .^{2}$

\subsection{Exchange rate policy and real output growth in Sierra Leone, 1970-2006}

As mentioned above, Sierra Leone provides a unique context for an econometric examination of the relationship between real exchange rate and real output growth because of its foreign exchange rate policy. Sierra Leone has experienced six exchange rate regimes since 1964. ${ }^{3}$ These regime changes are indicative of the importance attached to the exchange rate, possibly as one of the stable instruments for the monetary authority in its desire to achieve macroeconomic stability. In its first exchange rate regime, which spanned almost one and a half decades (between 1964 and 1978), the leone (Le) ${ }^{4}$ was pegged to the British pound sterling at the rate of two leones to the pound. The leone was devalued by 14.3 per cent in 1967, following the devaluation of the pound sterling in order to prevent capital flight and a drain on Sierra Leone's external reserves. Sierra Leone entered its second exchange rate regime in November 1978, when the leone was delinked from the British pound and was pegged to the International Monetary Fund's (IMF) Special Drawing Rights (SDR) at the rate of one leone to $0.731566 \mathrm{SDR}$. This peg to the SDR amounted to a 5 per cent devaluation of the Leone. The justification for delinking the leone from the British pound was that the pound could no longer be considered a strong anchor for protecting the leone and the economy from adverse external shocks relating to the diversified trade patterns. Thus, the link to the SDR was viewed as both timely and necessary, because the SDR represents a basket of major currencies, and was therefore less susceptible to external shocks.

Sierra Leone's third exchange rate regime began in December 1982, with the introduction of an auction system referred to as the "twotier" or dual exchange rate system. This system allowed two exchange rates - the official rate for government or capital transactions, which remained fixed, and a commercial rate for all other transactions, which was determined on the basis of biweekly auctions carried out by the Central Bank. Sierra Leone entered its fourth exchange rate regime in 1983, when it abolished the "two-tier" system and pegged the leone to the United States dollar at an official rate of Le2.50 to the dollar (that is, Le2.50=\$1). The link to the dollar was inevitable, as the US dollar was the most commonly-used currency in the parallel market for foreign exchange at the time.

The fifth exchange rate regime started on 27 June 1986, with the introduction of a floating exchange rate (dirty float) structure. The floating exchange rate system stabilised 
at a rate of Le53 to the dollar $(\operatorname{Le} 53=\$ 1)$ in April 1987, and was later revalued at Le23 to the dollar (Le23 $=\$ 1$ ) by the end of August 1987. This move was influenced by the need to appreciate the leone with the intention of stemming down inflationary pressures in the economy. The sixth exchange rate regime in Sierra Leone began in the early 1990s, when the exchange rate was fully liberalised (clean float) after the adoption of SAP in 1989. This was an attempt to restore macroeconomic stability and provide a solid foundation for private sector-led growth. The Structural Adjustment Programme (SAP) package included price liberalisation, exchange rate adjustment (market-determined exchange rate), trade policy reforms, public enterprise and fiscal reforms which involved the reduction in subsidies, increases in revenue collection, and rationalisation of public spending. Exchange rate adjustments through devaluation ${ }^{5}$ were pivotal to SAP, and the monetary authority used devaluation as a means of restoring macroeconomic stability through increases in real output growth and improvements in the external balances. The current "clean float" exchange rate, although determined by market forces, allowed the government to intervene periodically in order to regulate and prevent excessive depreciation of the leone. This was accomplished through the foreign exchange auction normally held by the Central Bank on a weekly basis.

Given the experience of Sierra Leone under the six exchange rate regimes discussed above, and based on the notion that persistent real overvaluation has adverse effects on economic growth, as well as the fact that the impact of real depreciation on real output is ambiguous. According to empirical findings, the main issue for empirical analysis is therefore whether a small open economy like Sierra Leone gained in terms of real output growth from its policy of exchange rate devaluations. This issue would be better handled with modern econometric analysis. However, before this is carried out in the next section, it is important to provide visual graphic perusals of both nominal and real exchange rate depreciations in Figure 1 and real output growth in Figure 2, to see how the real output growth responded to devaluations of the leone throughout the sample period. In Figure 1, what appears to be co-movements of the nominal and real effective exchange rate depreciation can be seen. Trends in the real exchange rate mimic the corresponding nominal exchange rate. The figure revealed a series of depreciation. However, the highest rate of both nominal and real exchange rate depreciations occurred during 1987 and 1991.

Figure 1

Nominal and real exchange rate depreciation
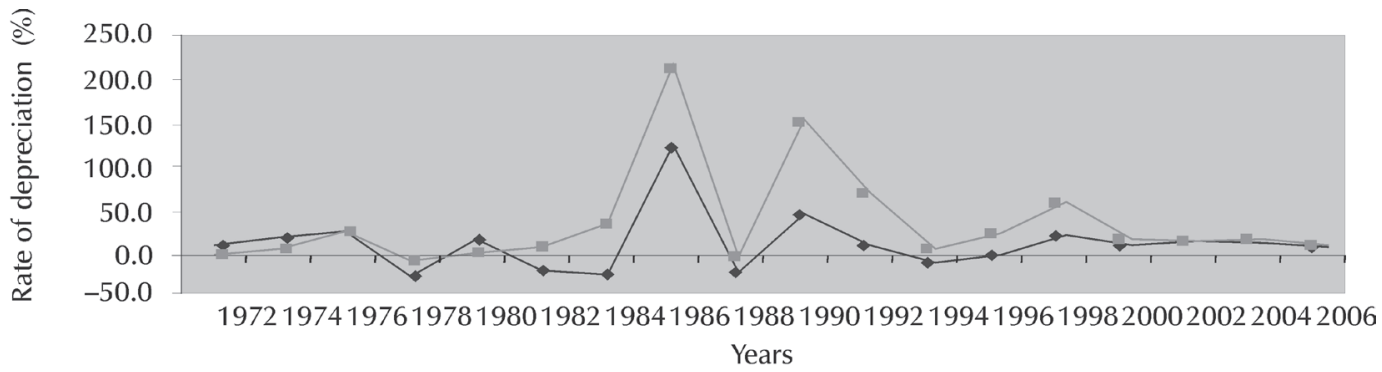

$\rightarrow$ Real effective exchange rate

- Nominal exchange rate 


\section{Figure 2}

Real GDP growth rate

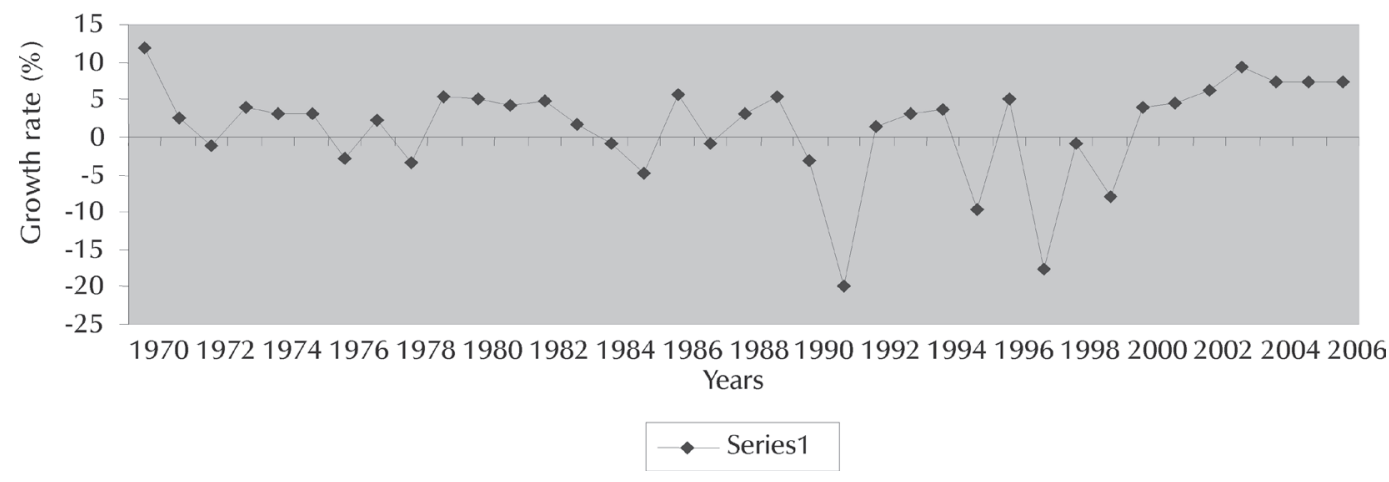

As for the growth of real GDP in Figure 2, one can see that there have been positive and negative real GDP growth rates since the 1970s. A close look at figures 1 and 2 show that real GDP growth was above 5 per cent in 1987, when Sierra Leone had its highest real exchange rate depreciation. In addition, real GDP growth on average was noticeably negative in the 1990s, despite positive growth during 1992, 1993, 1994 and 1996 being recorded. The 1990s were marred by the civil war and the period also coincided with the introduction of the "clean float" in 1990. As a matter of fact (as shown in Figure 2), fluctuations in the real GDP growth rate were more noticeable after the introduction of the market-based exchange rate system in 1986, which saw a series of exchange rate fluctuations.

\section{3}

\section{Determinants of the real effective exchange rate}

\subsection{Literature review}

There is a diverse body of studies on the determinants of the real exchange rate. Real exchange rate stability and its correct alignment are known to be necessary conditions for economic development. This agreement has resulted in numerous research works on the determinants of real exchange rate in both developed and developing countries. For instance, Aron et al. (1997) investigated the determinants of the real exchange rate in South Africa, using quarterly data for the period 1970:1-1995:1. They specified an errorcorrection model (ECM) and used ordinary least square (OLS) estimation techniques with trade policy, terms of trade, capital inflows, government expenditure and per capita real GDP growth as explanatory variables. The long-run equilibrium result showed that all the exogenous variables had a depreciating effect on the real exchange rate and were statistically significant. The short run equilibrium ECM result showed that nominal devaluation and domestic credit are both statistically significant and had a depreciating effect on the real exchange rate. In a related study, Parikh (1997) also examined the behavior of the real exchange rate in South Africa between 1979 and 1994 using monthly data. He used a vector autoregressive (VAR) framework and employed the Johansson maximum likelihood procedure. His findings showed that domestic debt, foreign debt, an increase in the gold price and change in productivity growth caused the real exchange rate to depreciate, and the coefficients were statistically significant.

Kemme and Roy (2005) examined both the short- and long-run movements in the real exchange rate for Poland and Russia, using both the Engel Granger static OLS procedure (for long-run estimation) and the Johansson procedure (for the number of co-integrating vectors). They used terms of trade, openness, net capital inflow, the ratio of total government 
expenditure to GDP, nominal devaluation and excess supply of domestic credit as explanatory variables in an ARIMA and GARCH error correction specification and employed OLS estimation techniques to determine the values of the coefficients. They found all the estimated coefficients, except that of openness, to be statistically significant at the 5 per cent level in the long run for both countries. Their results showed that an increase in government expenditure and capital inflow led to the depreciation of the real exchange rate, while the terms of trade had an appreciating effect. Openness, on the other hand, was significant at 10 per cent and led to an appreciation of the real exchange rate in both countries. Except for the terms of trade for Russia, the ECM revealed that all the fundamentals were statistically significant for both countries. In addition, nominal devaluation and an excess supply of credit were significant in both countries and caused an appreciation of the real exchange rate.

Eita and Sichei (2006) estimated an equilibrium real exchange rate and real exchange rate misalignment in Namibia during the period 1970-2004. They used a VAR model employing the Johansson (1988) FIML procedure. They included in their estimation terms of trade, openness and investment to GDP as explanatory variables, and found that an increase in openness and the ratio of investment to GDP caused an appreciation of the real exchange rate, while terms of trade caused depreciation. Hyder and Mahbood (2006) conducted a study on equilibrium real effective exchange rate misalignment for Pakistan, using annual data from 1978-2005. Using the Engle Granger cointegration technique, they estimated an ECM, employing an OLS estimation technique. The exogenous variables in their model included openness, terms of trade, real investment to GDP, government consumption as a percentage of GDP, workers' remittances as a percentage of GDP, long-term capital to GDP, and total factor productivity differential. The long-run result showed that openness, the increase in government consumption and capital inflow caused depreciation in the real effective exchange rate, while an increase in real investment to real GDP and improvement in the total factor productivity differential led to real effective exchange rate appreciation.

As the review of studies above has indicated, different empirical results from researchers were due to differences in modelling frameworks (tradable goods model, the Mundell-Fleming model, the dependent economy model and the importable-exportable goods model) for their analyses.

\subsection{Model of real effective exchange rate}

In this study, the real effective exchange rate (REER) is used in the analysis, since Sierra Leone has four major export trading partners. The theoretical model for the REER determination is based on the importableexportable goods framework, which is suitable for developing countries because it summarises the incentives that guide resource allocation across tradable and non-tradable sectors, but, more importantly, it allows for both nominal and real factors as determinants in the short run. ${ }^{6}$ To identify the determinants of REER for Sierra Leone during its exchange rate regimes, we follow the models used by Edwards (1988, 1989) and Elbadawi (1994). These models show that the real effective exchange rate dynamics are determined by three main factors: (a) the extent to which the actual REER deviates from its long-run equilibrium real effective exchange rate (ERER) level, (b) macroeconomic policy impact, which reflects the deviation of the fiscal and monetary policies $\left(Z_{t}^{*}\right)$, and (c) the nominal effective exchange rate $\left(e_{t}\right)$ changes. Based on these determinants, the real effective exchange rate equation is expressed as:

$\Delta \ln$ reer $_{t}=\theta\left(\ln\right.$ ERER $_{t}-\ln$ reer $\left._{t-1}\right)-\Phi\left(Z_{t}-Z_{t}^{*}\right)+\Omega\left(\ln e_{t}-\ln e_{t-1}\right) 0<\theta, \Phi$, and $\Omega<1$

where $\Delta$ is the difference operator, $\ln$ is the natural $\log$ and $t$ is time subscript. Equation (1) can also be rewritten as follows, assuming $(1-\theta)=0$

$\ln$ reer $_{t}=\theta(\ln$ ERER $)-\Phi\left(Z_{t}-Z_{t}^{*}\right)+\Omega\left(\ln e_{t}-\ln e_{t-1}\right)^{7}$ 
Based on conventional macroeconomic fundamentals, the determinants of the equilibrium

$\ln E R E R=f(\ln T O T, \ln O P E N, \ln I N V, \ln G C N)$

Where TOT is terms of trade, OPEN is openness of the economy, $I N V$ is the ratio of investment to GDP and $G C N$ is the ratio of total government consumption to GDP.

To derive an estimable REER equation for Sierra Leone, we substituted equation (3) into equation (2) and replaced the macroeconomic policy vector $\left(Z_{t}-Z_{t}^{*}\right)$ and the nominal exchange real effective exchange rate $(E R E R)$ can be expressed in functional form as:

rate changes $\left(\ln e_{t}-\ln e_{t-1}\right)$ with excess supply of domestic credit $(E S C)$ and the nominal effective exchange rate $(N E R)$ movements, respectively. It is important to point out here that ESC is an important monetary policy variable in many developing countries in Sub-Saharan Africa. The REER equation to be estimated in logarithmic form is expressed as:

$\ln$ reer $_{t}=\alpha_{0}+\alpha_{1} \ln T O T_{t}+\alpha_{2} \ln O P E N_{t}+\alpha_{3} \ln I N V_{t}+\alpha_{4} \ln G C N_{t}-\Phi E S C_{t}+\Omega N E R_{t}+\lambda D_{t}+\mu_{1}$

Where $\alpha_{1}, \alpha_{2}, \alpha_{3}$ and $\alpha_{4}$ are ambiguous (that is, the coefficients of these variables could be positive or negative), $\Phi, \Omega, \lambda>0^{8}, \mu_{1}$ is the error term that is identically and independently normally distributed with mean zero and constant variance, and $D$ is a binary dummy variable to capture the effects of the war years on real exchange rate determination (where; $\mathrm{D}=1$ for war periods and 0 otherwise) in Sierra Leone.

The data are from the International Financial Statistics CD-ROM 2007. The data used include REER, ${ }^{9}$ terms of trade (TOT), ${ }^{1}$ openness (OPEN), ${ }^{1}$ the ratio of total investment to GDP (Inv), the ratio of total government consumption to GDP (Cons), and nominal effective exchange rate. The variables are expressed in natural logarithms.

The results (reported in Appendix A) are quite satisfactory and the signs of the coefficients were consistent with economic theory. The coefficients are correctly signed and statistically significant at the conventional level of significance. Specifically, terms of trade (TOT) were negative with a statistically significant coefficient. An improvement in the terms of trade increased the real income of the economy, which created an increase in the demand for non-tradables. The high domestic demand then caused an increase in the domestic price level, which resulted in an appreciation of the real exchange rate, indicating a dominance of the income effect over the substitution effect.
A positive relationship was evident between nominal and real effective exchange rate, implying that a depreciation of the nominal effective exchange rate (NER) would generate real effective exchange rate depreciation. It shows that 10.0 per cent depreciation of the nominal effective exchange rate would lead to 2.9 per cent depreciation of the real effective exchange rate. The coefficient of investment to GDP ratio (INV) is positive and statistically significant at the 5 per cent level. This result showed that an increase in investment would lead to a depreciation of the REER. A plausible explanation for such a result is that an increase in investment would increase production of non-tradables, resulting in a decrease in their prices. The fall in domestic prices brought about by increased investment would result in a depreciation of the REER.

The coefficient of excess credit (ESC) is negative and statistically significant. This suggests that monetary variables tend to have an appreciating effect on the REER. Intuitively, an increase in money supply will lead to an increase in the demand for non-tradables, resulting in an increase in their domestic prices, which ultimately causes REER appreciation. Finally, the coefficient of the error correction term $(E C T)$, which measures the speed of adjustment, is statistically significant, with the expected negative sign and a magnitude of -0.1, denoting a slower speed of adjustment to longrun equilibrium. The general wisdom is that 
the closer the coefficient of ECT is to zero, the lower the speed of adjustment and the closer it is to one, the higher the speed of adjustment. Overall, the coefficient of determination as reported by the $R^{2}$ value shows that about 47.0 per cent of the variations in the dependent variable can be accounted for by the explanatory variables. The F-statistics were robust, as was evidenced by a significant probability value, suggesting an overall goodness of fit of the model. In addition, a Durbin-Watson value of approximately 1.90 does not indicate signs of serial autocorrelation.

\section{4 \\ Real effective exchange rate and economic growth}

\subsection{Literature review}

Given that the real exchange rate is one of the most important relative prices in an economy, it can be argued that a sound exchange rate policy is a crucial condition for improving economic performance in Sierra Leone. The adverse impact of RER misalignment on growth is stressed by Cottani et al. (1990), who assert that, despite many channels through which policy affects performance, there are many instances in which RER is the main transmission mechanism. An overvalued exchange rate hurts the exports sector and exposes competing import industries to fierce competition from foreign companies. Overvaluation may lead to tight monetary and fiscal policy (in an attempt by authorities to defend the currency), capital flight (in anticipation of devaluation), severe decline in foreign direct investment and technological transfers, and a chronic economic recession.

Edwards (1985) employed a reducedform equation for 12 developing countries using annual data for the period 1965-1980. He regressed real output on money growth surprises, government expenditure, terms of trade, and the real exchange rate. His empirical findings showed that the initial contractionary effects of real devaluation are reversed after one year and that devaluation is neutral in the long run. Kamin and Klau (1998) used an error correction technique to examine the relationship between real output and real exchange rate for a group of 27 countries. They did not find that devaluations were contractionary in the long term. Additionally, through the control of the sources of spurious correlation, reverse causality appeared to alternate the measured contractionary effects of devaluation in the short term, although the effect persisted even after the introduction of controls.

Ghura and Grennes (1993), based on pooled time series and cross-section data for 33 subSaharan African countries, found a negative relationship between RER misalignment and economic performance. They concluded that inappropriate domestic macroeconomic, trade and exchange-rate policies appeared to be one of the important factors that contributed to the economic distress in virtually all sub-Saharan African countries. Klau (1998) found that one of the main causes of poor economic performance in the CFA zone from the mid-1980s to the early 1990s was overvaluation of the CFA franc during that period.

Kuijs (1998) used quarterly data (1983:11996:4) to analyse the behaviour and determinants of inflation, exchange rate and real output in a macro-econometric model of the Nigerian economy. The ECM result for the real output equation revealed that an increase in the supply of foreign exchange increased output in the short run, while changes in real exchange rate were found to have no significant effect on short run output. In a similar study, Odusola and Akinlo (2001) used quarterly data (1970:11995:4) to investigate the link between the naira depreciation, inflation, and real output in Nigeria, employing the VAR approach. The variables in their VAR model included real GDP, money supply (M2), the official exchange rate, the parallel exchange rate, the consumer price index, and lending rates. Their results showed that exchange rate depreciation had an expansionary effect on real output in both the medium and the long term.

Recently, studies like that of Thapa (2002) examined the econometric relationship between the REER and economic activities (measured by GDP) in Nepal. The study used annual data from 1978-2000 and included GDP, REER 
government real total expenditure, and money supply as explanatory variables. The estimated ECM regression equation showed that the REER has a contractionary effect on economic activities. Yu Hsing (2005) employed the IS-LM model to find a possible relationship between real GDP and selected macroeconomic variables, which included the real exchange rate for Venezuela. Using annual time series data from 1959-2001, his study revealed that real depreciation of the bolivar raises real GDP growth. In a related study, Hsing and Hsien (2005) conducted a study on the impact of monetary, fiscal, and exchange rate policies on output in China, using a VAR approach for the period 1980-2000. Their explanatory variables included lending-interest rate, government debt ratio, inflation, and real GDP as explanatory variables; their result revealed that real appreciation of the exchange rate had a contractionary effect on output.

\subsection{Model and empirical results}

The main objective here is to investigate the link between the real effective exchange rate and economic growth (RGDP). An output growth model is thus specified by adding the REER to the set of explanatory variables generally included in empirical economic growth regressions. We specify the real output growth model using the basic IS-LM model (Gali, 1992; Yu Hsing, 2005) for an open economy. This has the advantage of tracing the impact of the real effective exchange rate on output. The real output growth equation to be estimated can be expressed as:

$$
\ln Y_{t}=\beta_{0}+\beta_{1} \ln M_{t}+\beta_{2} \ln \text { reer }_{t}+\beta_{3} \ln G_{t}+\beta_{4} P_{t}+\beta_{5} D_{t}+\mu_{2}
$$

Where $Y_{t}$ is real output growth, $M_{t}$ is broad money supply as a ratio of GDP, $G_{t}$ is ratio of government expenditure to GDP, $P_{t}$ is inflation rate; $D_{t}$ is a dummy variable for the war period and $\mu_{2}$ is the error term.

From equation (5), we expect the coefficients of monetary policy $\left(\beta_{1}\right)$ and fiscal policy $\left(\beta_{3}\right)$ variables to be positive. Further, we expect the coefficients of inflation $\left(\beta_{4}\right)$ and the war dummy $\left(\beta_{5}\right)$ variables to be negative while the real effective exchange rate $\left(\beta_{2}\right)$ variable is assumed to be ambiguous (that is, $\beta_{2}^{>} 0$ ).

The data for the study were sourced from the International Financial Statistics CD ROM 2007 (published by the International Monetary Fund), and various issues of the Bank of Sierra Leone Bulletin. The sample consists of quarterly data from 1990Q1-2006Q4, owing to the availability of data. The quarterly data were obtained through interpolation of annual time series data using Eviews 6.0. This was done using the low frequency to high frequency method and the quadratic match average and quadratic match sum for each observation of the low frequency series. Data used in the analysis include: Real GDP Growth (Y), Broad money M2 as a ratio of GDP (M), Government expenditure as a ratio of GDP (G) and Inflation rate (P); measured as the change in consumer price indices (CPI).

\section{Empirical results}

Valid estimation of the model requires an examination of the time-series properties of the data. Firstly, all time series data used in the estimation process were tested for stationarity. Appendix B gives the results of the standard Augmented Dickey-Fuller (ADF) and the Phillips and Perron (1988) tests, in which a unit root null hypothesis is tested against a stationary alternative.

Empirically, the null hypothesis of nonstationarity could not be rejected for all the variables in their levels. In other words, all the variables are non-stationary in levels, but become stationary after taking their first difference - an indication that all the variables are integrated of order one, I(1) series. It is important to note that differencing a variable to achieve stationarity can lead to long-run information loss. Thus, to determine whether a long-run relationship exists between the dependent and explanatory variables in the various models, we conducted a cointegration test. Individual time series data might be non-stationary but their linear combination might be stationary, which implies the existence of cointegration. We employed the Johansen Maximum cointegration test (Johansen \& Juselius, 1990), which is superior to the Engle-Granger (1987) two-step algorithm; 
and the short-run dynamics can be described by means of an error correction model (ECM), which can then be estimated using an ordinary least square (OLS) estimation technique. Both the Maximum Eigen values and Trace statistics revealed the existence of one co-integrating vector as evident in Appendix C. The existence of cointegration implies the estimation of an ECM, representing the short-run dynamics.

However, in this paper, both long-run and short-run estimations were carried out in order to fully investigate the impact of the real effective exchange rate on output growth, as well as determining the effectiveness of both fiscal and monetary policies on output growth during these two periods.

The long-run estimates of the real output growth are given in Table 2. The parameters were estimated using the OLS estimation technique and employing Hendry's general-tospecific modelling approach to arrive at a more parsimonious model. A lag length of one (1) was chosen as the appropriate lag length based on the Akaike Information Criterion (AIC) and the Schwarz SC tests. The results indicated that the REER had a positive effect on real output growth with a statistically significant coefficient. It is implicit in the result that a depreciation of the REER would increase real output growth in the long run. Intuitively, a real depreciation would increase the domestic price of imports and reduce the foreign price of domestic exports, thereby increasing exports and reducing imports, resulting in an increase in net export and correspondingly increasing output growth through the multiplier effect.

The monetary policy variable (M) is statistically significant with a positive sign implying that an increase in money supply will increase real output growth in the long run. This result, which is consistent with economic theory, is predicated on the standard IS-LM framework. The results validate the argument that an expansionary monetary policy (engendered by an increase in money supply) that reduces interest rates leads to output growth, partly because it spurs investment. This outcome works via the multiplier-accelerator effect. Using a different approach, Bangura et al. (2001) found a similar result for Sierra Leone. Furthermore, a positive relationship was identified between government expenditure as a ratio of GDP and output growth with a statistically significant coefficient. An expansionary fiscal policy (i.e. increase in government expenditure) would increase output growth via the multiplier effect on the domestic economy. Over the years, government expenditure has been mainly on infrastructure such as electricity, road maintenance and construction. This complements private-sector investment, resulting in increased output growth.

Table 2

Long run dynamics of real output growth $\left(Y_{t}\right)$

\begin{tabular}{|l|c|c|c|c|}
\hline \multicolumn{1}{|c|}{ Variable } & Coefficient & Std. Error & t-Statistic & Prob. \\
\hline $\mathrm{C}$ & 0.042780 & 0.005388 & 7.939847 & 0.0000 \\
\hline $\ln \mathrm{M}_{\mathrm{t}}$ & 0.295965 & 0.039785 & 7.439117 & 0.0000 \\
\hline $\ln \mathrm{reer}_{\mathrm{t}-1}$ & 0.049496 & 0.013007 & 3.805419 & 0.0002 \\
\hline $\ln \mathrm{G}_{\mathrm{t}-1}$ & 0.080993 & 0.016905 & 4.791009 & 0.0000 \\
\hline $\mathrm{D}_{\mathrm{t}}$ & -0.107688 & 0.033114 & -3.252027 & 0.0014 \\
\hline \multicolumn{5}{|c|}{ Diagnostic tests } \\
\hline R-squared & 0.485129 & \multicolumn{2}{|l}{ Mean dependent variable } & 0.063890 \\
\hline Adjusted R-squared & 0.469985 & \multicolumn{4}{|l}{ S.D. dependent variable } & -3.166624 \\
\hline S.E. of regression & 0.048818 & Akaike info criterion \\
\hline
\end{tabular}




\begin{tabular}{|l|c|l|c|}
\hline Sum squared residual & 0.324113 & Schwarz criterion & -3.062059 \\
\hline Log likelihood & 228.2470 & F-statistic & 32.03591 \\
\hline Durbin-Watson stat & 1.815118 & Prob(F-statistic) & 0.000000 \\
\hline \multicolumn{2}{|c|}{ Ramsy RESET test } & 0.7900 \\
\hline F-statistics & 0.078699 & Probability (2,31) & 0.7548 \\
\hline Log likelihood ratio & 0.090884 & Probability chi-square (2) & 0.75 \\
\hline
\end{tabular}

An inverse relationship existed between the war dummy and output growth, with a statistically significant coefficient. This result was not surprising, as the civil war caused massive disruption to vital sectors of the economy, such as agriculture, manufacturing, and mining, notwithstanding the collapse of essential public services in health and education, with the resultant consequences of reduced output growth. Moreover, the results showed that 49 per cent of the variations in the dependent variable are accounted for by the explanatory variables. The F-statistics revealed an overall goodness of fit of the model, with no evidence of serious serial correlation. The Ramsey
Regression Specification Error (RESET) test showed that the f-values are quite small and their corresponding p-values of 0.7900 and 0.7548 are well above the conventional significance level of 0.05 . There is no evidence from the RESET test to suggest that the longrun real output growth model is inadequate, so the model is well specified. Comparison of the beta coefficients revealed that all the key variables had a positive effect on long-run output growth. However, the result showed that the REER had the least effect on output growth, while monetary policy was found to be more effective than fiscal policy in the long run, as is evident in Table 3.

Table 3

Beta coefficients for growth determinants ${ }^{12}$

\begin{tabular}{|l|c|c|}
\hline \multicolumn{1}{|c|}{ Variables } & Beta coefficients & \multicolumn{1}{c|}{ Rank } \\
\hline $\ln \mathrm{M}_{\mathrm{t}}$ & 0.241201 & $1^{\text {st }}$ \\
\hline In reer & 0.013188 & $3^{\text {rd }}$ \\
\hline $\ln \mathrm{G}_{\mathrm{t}-1}$ & 0.028047 & $2^{\text {nd }}$ \\
\hline
\end{tabular}

In the ECM, the lagged value of the error correction term (ECT) was used as an independent variable to determine the speed of adjustment. The ECM estimation results as displayed in Table 4 showed that output growth in the short run is partly explained by money supply, inflation rate, and civil unrest. The coefficient of money supply is positive and statistically significant, in line with the standard IS-LM doctrine for an open economy. In addition, domestic inflation rate is negatively related to real income growth in the short run and statistically significant even at the 1 per cent significance level. Thus, a higher inflation rate will lead to a fall in real output growth. A plausible explanation for such a result is that a rising inflation rate would cause inconvenience, distortions, inefficiency, misallocation of resources and menu costs, which would harm real output growth. 
Table 4

Short run dynamics of real output $\left(Y_{t}\right)$ growth

\begin{tabular}{|l|c|c|c|c|}
\hline \multicolumn{1}{|c|}{ Variable } & Coefficient & Std. error & t-Statistic & Prob. \\
\hline $\mathrm{C}$ & 0.062592 & 0.005137 & 12.18551 & 0.0000 \\
\hline$\Delta \mathrm{ln} \mathrm{M}_{\mathrm{t}}$ & 0.329052 & 0.096878 & 3.396558 & 0.0009 \\
\hline In $\mathrm{P}_{\mathrm{t}-1}$ & -0.393023 & 0.102179 & -3.846428 & 0.0002 \\
\hline $\mathrm{D}_{\mathrm{t}}$ & -0.052130 & 0.022645 & -2.302082 & 0.0229 \\
\hline ECT $_{\mathrm{t}-1}$ & -0.292155 & 0.063186 & -4.623728 & 0.0000 \\
\hline & & & \\
\hline R-squared & 0.389409 & Mean dependent var & 0.063902 \\
\hline Adjusted R-squared & 0.365925 & S.D. dependent var & 0.072068 \\
\hline S.E. of regression & 0.057387 & Akaike info criterion & -2.834887 \\
\hline Sum squared residual & 0.428123 & Schwarz criterion & -2.706387 \\
\hline Log likelihood & 198.7723 & F-statistic & 16.58173 \\
\hline Durbin-Watson stat & 1.224267 & Prob(F-statistic) & 0.000000 \\
\hline
\end{tabular}

As in the long-run equation, the war dummy variable had a negative impact on real output growth with a significant coefficient. The coefficient of the ECT was negative and fell within the accepted region. A value of 0.29 implies that the short-run dynamic converges to its long run cointegrating relationship with a relatively low speed of adjustment.

\section{Granger causality test}

The focus in this sub-section is to conduct a Granger causality test between the REER and real GDP. The rationale is to detect the causality between the REER and real GDP in the context of a bivariate model, which is defined as follows:

$\mathrm{Y}_{t}=\beta_{0}+\sum_{i=1}^{n} \beta_{1 i} Y_{t-1}+\sum_{i=1}^{m} \beta_{2 i}$ reer $_{-1}+\varepsilon_{1}$
Where $\varepsilon_{1}$ is a white noise error term, $\mathrm{Y}$ is real GDP and the REER is the real effective exchange rate. Equation (6) represents causality running from the REER to Y. The null hypothesis to be tested would be that the REER does not Granger cause Y. The null would be accepted if $\sum \beta_{2 i}$ was equal to zero simultaneously. The corresponding null hypothesis to the above will be that Y does not Granger cause the REER, and this is specified as follows, where the REER is the dependent variable:

reer $_{t}=\alpha_{0}+\sum_{k=1}^{q} \alpha_{1 i}$ reer $_{t-k}+\sum_{k=1}^{p} \alpha_{2 i} Y_{t-1}+\varepsilon_{2}$

where $\varepsilon_{2}$ is a white noise error term and other variables are as defined earlier. From equation (7), we say that the null hypothesis will be accepted if $\sum \alpha_{2 i}$ is equal to zero simultaneously.

\section{Table 5}

Bivariate Granger causality test results

\begin{tabular}{|l|c|c|}
\hline \multicolumn{1}{|c|}{ Null hypothesis } & F-statistics & P-value \\
\hline $\begin{array}{l}\text { Dependent variable } \boldsymbol{Y} \\
\text { Reer does not Granger cause Y }\end{array}$ & 10.1884 & 0.00175 \\
\hline $\begin{array}{l}\text { Dependent variable REER } \\
\text { Y does not Granger cause REER }\end{array}$ & 0.60993 & 0.43614 \\
\hline
\end{tabular}


The Bivariate Granger causality results in Table 5 reject the null hypothesis that the REER does not Granger cause real GDP at the 1 per cent level. The rejection of the null hypothesis is indicative that the REER causes growth in real GDP. However, the null hypothesis that real GDP does not Granger cause the REER cannot be rejected even at the conventional level.

\section{5}

\section{Conclusions and lessons for policy}

This paper has attempted to provide empirical estimates of the relationship between the REER and economic growth in Sierra Leone, employing the Johansson cointegration technique for the period 1990Q1-2006Q4. The formulation of the output model was anchored on sound economic theory. In addition to investigating the effect of the REER on output growth, the model has the advantage of establishing the relative effectiveness of fiscal and monetary policies on real output growth during the review period. Identification of the determinants of the REER was also pursued in this study.

The results of the long run indicate that the REER, monetary policy and fiscal policy all had a positive effect on output growth, while the civil war during the 1990s had an adverse effect on output growth in Sierra Leone during the review period. Specifically, a depreciation of the REER increased output growth, while increases in both money supply and government expenditure caused an increase in output growth through the multiplier effect. However, the beta coefficient revealed that monetary policy is relatively more effective than fiscal policy in the long run, while the REER was found to have the least effect on output growth. This finding is consistent with the basic Mundell-Fleming model, which indicates that monetary policy is more effective than fiscal policy under a flexible exchange rate regime. In the short run ECM, while monetary policy was found to have a positive impact on output growth, inflation and the civil unrest had a dampening effect on output growth.

Based on the findings, some useful policy lessons can be drawn from this study. Both fiscal and monetary policy increased output growth.
Thus, the objectives of monetary policy should be in consonance with that of fiscal policy in order to achieve macroeconomic stability consistent with sustainable real GDP growth and low inflation. In this regard, there should be a framework for effective co-ordination of fiscal and monetary policies. Further, nominal effective exchange rate depreciation leads to REER depreciation, which tends to increase net export and hence output growth. However, nominal depreciation might be inflationary in a complete exchange rate pass-through scenario. It is therefore necessary to maintain a stable exchange rate by allowing the exchange rate to depreciate within a given band. This policy recommendation is consistent with the convergence criterion on the exchange rate set by the West African Monetary Zone (WAMZ) ${ }^{13}$ in which the exchange rate is expected to depreciate within a band of $+/-15$ per cent for member countries. Finally, political instability impedes output growth. Thus, for a resurgence of investment, and hence output growth in Sierra Leone, a stable political environment is a sine qua non.

\section{Endnotes}

1 The real exchange rate is the nominal exchange rate (index) adjusted for price changes in the domestic economy relative to those of trading partners (Fosu, 1992); that is, RER $=\mathrm{EP}^{*} / \mathrm{P}$, where RER is real exchange rate, $\mathrm{E}$ is nominal exchange rate, $\mathrm{P}^{*}$ is foreign price level, and $\mathrm{P}$ is domestic price level.

2 See World Bank country briefing.

3 Bank of Sierra Leone Bulletin. 1997: 20.

4 The leone (Le) is the domestic currency denomination in Sierra Leone.

5 Devaluation involves a reduction in the value of the domestic currency vis-à-vis the currencies of its trading partners.

6 The model consists of exportable goods, importable goods and non-tradable goods (see Dorbusch, 1974).

7 Note that $\Delta \ln$ reer $_{t}=\ln$ reer $_{t}-\ln$ reer $_{t-1}$

8 A negative sign implies the impact of a given variable on the REER and leads to an appreciation of the real effective exchange rate, while a positive sign means that the effect of a variable causes a depreciation of the REER. 
9 The reert is weighted by the trade shares of exporting partners, and this is computed as:

reer $_{t}=\sum_{i=1}^{4} \alpha_{i}\left(\frac{e_{i} C P I_{i}^{*}}{C P I}\right)_{t}$

where $i$ represents the four major export partners of Sierra Leone, $\alpha_{i}$ is the weight or share of the $i$ th country in the total export of Sierra Leone, $\mathrm{CPI}_{i}{ }^{*}$ is the consumer price index of the $i$ th country, $e_{i}$ is the bilateral nominal exchange rate defined as leones per currency of the $i$ th country, $C P I$ is the domestic consumer price index.

10 Terms of Trade $=($ Export price index $/$ import price index $)^{*} 100$.

11 OPEN $=(\mathrm{X}+\mathrm{IM}) / \mathrm{GDP}$, where $\mathrm{X}$ is export and IM is import.

12 Beta coefficient $(\beta)$ of a variable is defined as follows: $\beta=$ (coefficient of the variable * standard error of the variable)/standard error of the regression. A higher beta coefficient means a stronger influence of that variable on the dependent variable. A lower beta coefficient means a weaker influence of the variable on the dependent variable.

13 Countries of the WAMZ include Gambia, Ghana, Guinea, Nigeria and Sierra Leone.

\section{References}

AGÉNOR, P.R. 1991. Output, devaluation and the real exchange rate in developing countries. Review of World Economies, 127(1): 18-41.

ARON, J., ELBADAWI, I.A. \& KAHN, B. 1997.

Determinants of the real exchange rate in South

Africa. Centre for the Study of African Economies, WPS/97-16, Oxford: CSAE Publishing.

BANGURA, A., DEEN, A., THOMAS, Y.; KWATENG, F. \& OKONTA, H. 2001. The relative effectiveness of monetary and fiscal policies in Sierra Leone. Bank of Sierra Leone Bulletin, July-December: 29-39.

COOPER, R. 1971. An assessment of currency devaluation in developing countries. Essays in International Finance, No. 86. Princeton, N.J.: Princeton University.

DICKEY, D.A. \& FULLER, W.A. 1981. Likelihood ratio statistics for autoregressive time series with a unit root. Econometrica, 49(4): 1057-1072.

EDWARDS, S. 1989. Real exchange rates, devaluation and adjustment: exchange rate policy in developing countries. Cambridge, MA: The MIT Press.

1985. Are devaluations contractionary? NBER Working Paper, No. 1676. Cambridge, Mass.: National Bureau of Economic Research.
EITA, J.H. \& SICHEI, M.M. 2006. Estimating the equilibrium real exchange rate for Namibia. University of Pretoria Working Paper, 2006-08, February. ELBADAWI, I.A. 1994. Estimating long-run equilibrium real exchange rates, in Williamson, John (ed.) Estimating equilibrium exchange rates, Institute for International Economics, Washington, DC.

ENGLE, R. \& GRANGER, C. 1987. Co-integration and error-correction: Representation, estimation and testing. Econometrica, 35: 251-276.

GALI, J. 1992. How well does the IS-LM model fit postwar U.S. data? Quarterly Journal of Economics, 107(2): 709-738.

GYLFASON, T. \& SCHMID, M. 1983. Does

devaluation cause stagflation? Canadian Journal of Economics 16(4): 641-54.

HENDRY, D.F. 1995. Dynamic econometrics: advanced texts in econometrics. Oxford University Press.

HSING, Y. \& HSIEN, W. 2005. Impacts of monetary, fiscal and exchange rate policies on output in China:

A VAR approach. Journal of Economic Literature, E5, F4, H6.

HSING, Y. 2005. Impact of monetary policy, fiscal policy, and currency depreciation on output: The case of Venezuela. Journal of Economic Literature, E5, F4. HYDER, J. \& MAHBOOD, A. 2006. Equilibrium real effective exchange rate and exchange rate misalignment in Pakistan. SBP Research Bulletin, 2(1). JOHANSEN, S. 1988. Statistical analysis of cointegration vectors. Journal of Economic Dynamics and Control, 12: 231-54.

JOHANSEN, S. \& JUSELIUS, K. 1990. Maximum likelihood estimation and inference on cointegration with applications to the demand for money. Oxford Bulletin of Economics \& Statistics, 52 : 169-210.

KAMIN, S.B. \& KLAU, M. 1998. Some multi-country evidence on the effects of real exchange rates on output. International Finance Discussion Paper, No. 611, Washington, D.C.: Board of Governors of the Federal Reserve System.

KEMME, D.M. \& ROY, S. 2005. Real exchange rate misalignment: Prelude to crisis? William Davidson Institute Working Paper, No. 797.

KUIJS, L. 1998. Determinants of inflation, exchange rate and output in Nigeria. IMF Working paper, WP/98/160 Nov.

MONTIEL, P. 1997. Exchange rate policy and macroeconomic management in ASEAN countries. In Hicklin, J. et al. (eds.) Macroeconomic issues facing ASEAN countries. Washington, D.C.: IMF.

MORLEY, S.A. 1992. On the effect of devaluation during stabilization programs in LDCs. Review of Economics and Statistics, 74(1): 21-27. 
ODUSOLA, A.F. \& AKINLO, A.E. 2001. Output, inflation and exchange in developing countries: an application to Nigeria. The Development Economies XXXIX-2.

PARIKH, A. 1997. Determinants of real exchange rate in South Africa: A short-run and long-run analysis. African Journal of Economic Policy, 14(1).

PHILLIPS, P.C.B. \& PERRON, P. 1988. Testing for a unit root in time series Regression. Biometrika, 75: 335-346.
PRICK, D.H. \& VOLLRATH, T.U. 1994. Real exchange rate misalignment and agricultural export performance in developing countries. Economic Development and Cultural Change.

SAID, E.S. \& DICKEY, D.A. 1984. Testing for unit roots in autoregressive-moving average models of unknown order. Biometrika, 71(3); 599-607.

THAPA, N.B. 2002. An econometric analysis of the impact of real effective exchange rate on economic activities in Nepal. Economic Review: Occasional Paper, No. 14, April. 
Appendix A

Dynamics of real effective exchange rate

(Parsimonious model)

\begin{tabular}{|c|c|c|c|c|}
\hline Variable & Coefficient & Std. error & t-Statistic & Prob. \\
\hline $\mathrm{C}$ & -0.036696 & 0.043013 & -0.853133 & 0.4006 \\
\hline$\Delta \mathrm{ln} \mathrm{TOT}_{\mathrm{t}-1}$ & -0.294804 & 0.094004 & -3.136069 & 0.0039 \\
\hline$\triangle \ln N_{E R}$ & 0.279821 & 0.077325 & 3.618760 & 0.0011 \\
\hline$\Delta \ln I N V_{t-1}$ & 0.390786 & 0.161664 & 2.417274 & 0.0222 \\
\hline$\Delta \ln \mathrm{ESC}_{\mathrm{t}-1}$ & -0.144522 & 0.052516 & -2.751935 & 0.0101 \\
\hline $\mathrm{ECM}_{\mathrm{t}-1}$ & -0.108546 & 0.050101 & -2.166543 & 0.0378 \\
\hline \multicolumn{5}{|c|}{ Diagnostic tests } \\
\hline R-squared & 0.465210 & \multicolumn{2}{|c|}{ Mean dependent variable } & 0.017023 \\
\hline Adjusted R-squared & 0.373005 & \multicolumn{2}{|c|}{ S.D. dependent variable } & 0.235926 \\
\hline S.E. of regression & 0.186814 & \multicolumn{2}{|c|}{ Akaike info criterion } & -0.362605 \\
\hline Sum squared residual & 1.012081 & \multicolumn{2}{|c|}{ Schwarz criterion } & -0.095974 \\
\hline Log likelihood & 12.34559 & \multicolumn{2}{|l|}{ F-statistic } & 5.045383 \\
\hline Durbin-Watson stat & 1.858284 & \multicolumn{2}{|l|}{ Prob(F-statistic) } & 0.001904 \\
\hline
\end{tabular}




\section{Appendix B}

Stationarity test - unit root (constant and trend included)

\begin{tabular}{|c|c|c|c|c|c|}
\hline \multirow[t]{2}{*}{ Variables } & \multicolumn{2}{|c|}{ Augmented Dickey-Fuller test } & \multicolumn{2}{|c|}{ Phillip-Perron test } & \multirow{2}{*}{$\begin{array}{c}\text { Order of } \\
\text { integration }\end{array}$} \\
\hline & Levels & $1^{\text {st }}$ difference & Levels & $1^{\text {st }}$ difference & \\
\hline Reer & -2.497 & $-5.773^{* *}$ & -2.296 & $-5.724^{* *}$ & $\mathrm{I}(1)$ \\
\hline TOT $_{t}$ & -2.678 & $-5.459 * *$ & -2.488 & $-5.429 * *$ & $\mathrm{I}(1)$ \\
\hline OPEN $_{t}$ & -1.825 & $-5.511^{* *}$ & -1.115 & $-5.511^{* *}$ & $\mathrm{I}(1)$ \\
\hline $\mathrm{INV}_{\mathrm{t}}$ & -1.053 & $-5.752^{* *}$ & -0.3507 & $-5.734^{* *}$ & $\mathrm{I}(1)$ \\
\hline $\mathrm{GCN}_{\mathrm{t}}$ & -3.016 & $-5.605^{* *}$ & -2.111 & $-5.605^{* *}$ & $\mathrm{I}(1)$ \\
\hline $\mathrm{ESC}_{\mathrm{t}}$ & -1.577 & $-5.1076^{* *}$ & -1.553 & $-5.056^{* *}$ & $\mathrm{I}(1)$ \\
\hline $\mathrm{NER}_{\mathrm{t}}$ & -1.053 & $-5.459 * *$ & -0.3507 & $-4.959 * *$ & $\mathrm{I}(1)$ \\
\hline$Y_{t}$ & -1.339 & $-5.636^{* *}$ & -1.358 & $-5.461^{* *}$ & $\mathrm{I}(1)$ \\
\hline$M_{t}$ & -0.2819 & $-4.966^{* *}$ & 0.1705 & $-4.204^{*}$ & $\mathrm{I}(1)$ \\
\hline$G_{t}$ & -0.1069 & $-5.867^{* *}$ & -0.1364 & $-5.657^{* *}$ & $\mathrm{I}(1)$ \\
\hline $\mathrm{P}_{\mathrm{t}}$ & -0.7251 & $-5.046^{* *}$ & -0.5076 & $-4.925^{* *}$ & $\mathrm{I}(1)$ \\
\hline \multicolumn{6}{|c|}{ Critical values } \\
\hline \multicolumn{6}{|l|}{$\begin{array}{l}\text { Level of } \\
\text { significance }\end{array}$} \\
\hline $1 \%$ & \multicolumn{2}{|c|}{-4.535} & \multicolumn{2}{|c|}{-4.263} & \\
\hline $5 \%$ & \multicolumn{2}{|c|}{-3.612} & \multicolumn{2}{|c|}{-3.553} & \\
\hline $10 \%$ & \multicolumn{2}{|c|}{-3.209} & \multicolumn{2}{|c|}{-3.207} & \\
\hline
\end{tabular}

Note: ${ }^{* *}=1$ per cent level of significance, and $*=5$ per cent level of significance. 


\section{Appendix C}

Johansen cointegration test results (output equation)

\begin{tabular}{|l|c|c|c|c|}
\hline \multicolumn{1}{|c|}{$\begin{array}{c}\text { Hypothesised } \\
\text { no of CE(s) }\end{array}$} & Eigen value & Trace statistics & $\begin{array}{c}\text { 5 per cent critical } \\
\text { value }\end{array}$ & $\begin{array}{c}\text { 1 per cent critical } \\
\text { value }\end{array}$ \\
\hline None $* *$ & 0.426109 & 56.34029 & 47.21 & 54.46 \\
At most 1 & 0.274104 & 24.13198 & 29.68 & 35.65 \\
At most 2 & 0.086953 & 5.551780 & 15.41 & 20.04 \\
At most 3 & 0.004741 & 0.275656 & 3.76 & 6.65 \\
\hline
\end{tabular}

${ }^{*}\left({ }^{* *}\right)$ denotes rejection of the hypothesis at the 5 per cent ( 1 per cent) level

Trace test indicates 1 cointegrating equation(s) at both 5 per cent and 1 per cent levels

\begin{tabular}{|l|c|c|c|c|}
\hline \multicolumn{1}{|c|}{$\begin{array}{c}\text { Hypothesised } \\
\text { no of CE(s) }\end{array}$} & Eigen value & $\begin{array}{c}\text { Max-Eigen } \\
\text { STATISTICS }\end{array}$ & $\begin{array}{c}\text { 5 per cent critical } \\
\text { value }\end{array}$ & $\begin{array}{c}\text { 1 per cent critical } \\
\text { value }\end{array}$ \\
\hline None ${ }^{*}$ & 0.426109 & 32.20831 & 27.07 & 32.24 \\
At most 1 & 0.274104 & 18.58020 & 20.97 & 25.52 \\
At most 2 & 0.086953 & 5.276124 & 14.07 & 18.63 \\
At most 3 & 0.004741 & 0.275656 & 3.76 & 6.65 \\
\hline
\end{tabular}

${ }^{*}(*)$ denotes rejection of the hypothesis at the 5 per cent ( 1 per cent) level

Max-Eigen value test indicates 1 cointegrating equation(s) at the 5 per cent level Max-Eigen value test indicates no cointegration at the 1 per cent level 